IP Periodica Polytechnica

Transportation Engineering

46(3), pp. 151-157, 2018

https://doi.org/10.3311/PPtr.10824

Creative Commons Attribution (i)

RESEARCH ARTICLE

\section{Customer Satisfaction in the Field of Comprehensive Service of Refrigerated Containers in Seaports}

\author{
Ludmiła Filina-Dawidowicz $^{1 *}$, Teresa Gajewska ${ }^{2}$
}

Received 31 March 2017; accepted 19 February 2018

\begin{abstract}
The article analyzes the issues concerning customer satisfaction survey with the complexity of handling refrigerated containers at the seaports' container terminals. It aims to determine the criteria to evaluate the port comprehensive service and to examine the opinion of chosen seaports terminals on customer satisfaction with the complexity of handling refrigerated containers. Evaluation criteria of comprehensive service of refrigerated containers in seaports were identified and examined. The analysis of ports opinions on customer satisfaction with the service of refrigerated containers was based on surveys, which covered 5 container terminals located in the Polish cities of Gdansk, Gdynia and Szczecin. The research revealed that according to the ports, complex service primarily affects the high-level customer satisfaction and shorter service time, while implementation of this service regards a good level of customer service and price.
\end{abstract}

\section{Keywords}

customer satisfaction, comprehensive service, refrigerated containers, seaport, quality of services

\footnotetext{
${ }^{1}$ Faculty of Maritime Technology and Transport,

West Pomeranian University of Technology,

71-065 Szczecin, Poland

${ }^{2}$ Faculty of Mechanics, Section of Logistics System,

Cracow University of Technology,

31-155 Cracow, Poland

*Corresponding author, e-mail: ludmila.filina@zut.edu.pl
}

\section{Introduction}

Together with increasing globalization, development of international trade, transport techniques and technology, there is an increase in the volume of transported cargo, including food in refrigerated containers by maritime transport. On the basis of the Drewry Maritime Research report worldwide perishable reefer trade of goods in 2014 reached almost 190 million tons (Drewry, 2015). The growth of seaborne trade of perishable reefer goods was also strong (increased by $4.9 \%$ in 2014) and is projected to maintain the upward trend at least until 2018. This perspective force ports to adapt to predicted changes taking into consideration not only infrastructure and port facilities improvement (Corman et al., 2016), but also relations with their customers.

Perishable cargoes are delicate, have limited shelf life and require efficient service and care during port service (FilinaDawidowicz and Troynina, 2015). The requirements of flexible adjustment to changing demand for these loads cause that the owners of these cargoes more often decide to transport goods in refrigerated containers. Such containers allow them to provide i.e. cargo protection and loads' storage conditions monitoring, as well as sending small commodity loads through regular containerized supply chains (Rodrigue and Notteboom, 2014).

The ports services market is characterized by high level of competition, therefore, the observed development of logistics in seaports is accompanied by tightening of customers' requirements for the variety and quality of seaports services (Grzelakowski and Matczak, 2006; Pluciński, 2013). This forces the seaports to adapt their services to customers' requirements. Comprehensive service actually becomes not only a tool to attract customers, but also a service standard, aiming to meet customers' expectations and increase the level of their satisfaction.

Service quality and customer satisfaction are two very closely related and sometimes even identified concepts. Customer satisfaction is a key factor in assessing the quality of a service. If it is difficult to define the quality of service; it is even harder to determine the level of customer satisfaction (Meidute-Kavaliauskiene et al., 2014). The idea of customer satisfaction can be defined in different ways in literature. According to Kotler's et al. (2000) definition customer 
satisfaction is "feeling, that to experience purchaser after the service is used which fulfil his expectations". According to Yi (1989), customer satisfaction may be defined in two basic ways, either as an outcome, or as a process (Table 1):

- the first approach defines satisfaction as a final situation or as an end-state resulting from the consumption experience;

- the second one emphasizes the perceptual, evaluative and psychological process that contributes to satisfaction.

Satisfaction measurement delivers information about organization and satisfaction level of customer needs in an efficient way. During customer satisfaction evaluation different scope of guild services may be considered (Lisińska-Kuśnierz and Gajewska, 2014), as well as the main principles of continuous improvement of enterprises could be developed (Gajewska and Grigoroudis, 2015).

Thus, both customer satisfaction and logistics service quality are very important in the current business environment, as the relationship between the service provider and the client is usually long-term (or it is attempted to be kept). For the relationship to be long term, a logistics service provider has to provide a service in line with the customers' expectations, leading to ensure the high level of customer satisfaction (Caceres and Paparoidamis, 2007).

Table 1 Definitions of customer satisfaction (Grigoroudis and Siskos, 2010; Yi, 1989)

\begin{tabular}{|c|c|c|}
\hline Approach & Definition & Author \\
\hline \multirow{4}{*}{$\begin{array}{c}\text { Satisfaction as } \\
\text { an outcome }\end{array}$} & $\begin{array}{l}\text { The buyer's cognitive state of being } \\
\text { adequately or inadequately rewarded for } \\
\text { the sacrifices he has undergone }\end{array}$ & $\begin{array}{l}\text { Howard and } \\
\text { Sheth (1969) }\end{array}$ \\
\hline & $\begin{array}{l}\text { An emotional response to the } \\
\text { experience provided by (or associated }\end{array}$ & Westhrok and \\
\hline & $\begin{array}{l}\text { purchased, retail outlets, or even molar } \\
\text { patterns of behaviour, as well as the } \\
\text { overall marketplace }\end{array}$ & $\begin{array}{l}\text { Westbrook and } \\
\text { Reilly (1983) }\end{array}$ \\
\hline & $\begin{array}{l}\text { An outcome of purchase and use } \\
\text { resulting from the buyer's comparison } \\
\text { of the rewards and the costs of the } \\
\text { purchase in relation to the anticipated } \\
\text { consequences }\end{array}$ & $\begin{array}{l}\text { Churchill and } \\
\text { Suprenant } \\
\text { (1982) }\end{array}$ \\
\hline \multirow{3}{*}{$\begin{array}{c}\text { Satisfaction as } \\
\text { a process }\end{array}$} & $\begin{array}{l}\text { An evaluation rendered that the } \\
\text { experience was at least as good as it was } \\
\text { supposed to be }\end{array}$ & Hunt (1977) \\
\hline & $\begin{array}{l}\text { An evaluation that the chosen alternative } \\
\text { is consistent with prior beliefs with } \\
\text { respect to that alternative }\end{array}$ & $\begin{array}{c}\text { Engel and } \\
\text { Blackwell } \\
(1982)\end{array}$ \\
\hline & $\begin{array}{l}\text { The consumer's response to the } \\
\text { evaluation of the perceived discrepancy } \\
\text { between prior expectations and the } \\
\text { actual performance of the product as } \\
\text { perceived after its consumption }\end{array}$ & $\begin{array}{c}\text { Tse and Wilton } \\
\text { (1988) }\end{array}$ \\
\hline
\end{tabular}

In recent years along with the development of logistics, there have been some changes in the approach and the way of transport and logistics chains functioning, since the role of seaports in these chains is strongly emphasized (FilinaDawidowicz and Wiktorowska-Jasik, 2013; Lorenc and Więcek, 2014). Along with it, in seaports the group of logistics services is actively developed year on year, near the ports or their close areas logistics centres are built. Furthermore, ports aspire to the role of logistics service providers, offering growing number of high quality services.

In order to examine the ports customers' satisfaction of the port services the surveys are carried out. These are generally questionnaire surveys filled by ports customers, including shipping agencies and lines, etc. The scope of the research includes both port and its authority, as well as selected terminals operators. Jafari et al. (2013) accessed the satisfaction of container shipping lines from port services as well as conducted the prioritization of the factors affecting customer satisfaction in Iraqi container ports. Zhang et al. (2010) analyzed the quality management of customer satisfaction in the port authority. Dehdaril and Jafari (2013) conducted an empirical study on customer satisfaction in Pakistanian container ports applying the Kano model.

Moreover, there is a number of publications presenting the multi-criteria decision methodology used for improvement of transport and logistics systems functioning (Grzybowska and Kovács, 2017; Kovács and Bóna, 2009; Esztergár-Kiss and Csiszár, 2016; Galkin, 2015). However, there is lack of literature positions showing the multicriteria evaluation of factors forming the comprehensive service of perishable goods in container terminals.

So far, there have been no research papers on customer satisfaction with the comprehensive service of refrigerated containers in seaports. These studies could include both assessment of port clients and its customer's opinion. Especially interesting is to examine port's opinion concerning importance of offering of these services.

The article aims to determine the criteria for comprehensive service assessment of refrigerated containers in seaports and examine the seaports opinion on customer satisfaction with the complexity of handling this cargo in container terminals. The scope of the research includes container terminals located in Polish cities of Gdansk, Gdynia and Szczecin.

\section{Comprehensive service of refrigerated containers in seaports}

According to Grzelakowski and Matczak (2006) the process of cargo and vehicles servicing at seaports is an ordered sequence of organizational and logistical, technical and technological, economic and legal processes, actions and activities which are the part of a widely understood cycle of goods moving from their place of production (extraction) to the places of their consumption (processing). 
The concept of the comprehensive services in seaports has been mentioned in several studies (Filina-Dawidowicz and Wiktorowska-Jasik, 2013; Grzelakowski and Matczak, 2006). This issue relates to the execution of services both disposable (connected with planning and organization of ships, loads and vehicles service) and technical (dealing with operations execution, such as overloading, storage, repair etc.) (Misztal et al, 2010). The main benefit of services complexity is the ability to perform the duties in shorter time and to reduce the number of formalities during separate services implementation by many contractors. These actions follow the needs of flexible and the best match of seaport offer to the clients' expectations, among which the opportunity of complex realization of logistical tasks in port and the ability to enrich its offer of value added services can be distinguished (Filina-Dawidowicz and Wiktorowska-Jasik, 2013).

Grant, Lambert, Stock, and Ellram (2006) considered that comprehensive customer service program should include three groups of elements: pre- transaction - aimed at preparing the organization for customer service, transaction - dealing with customer direct contact with the company and efficient transactions execution in accordance with the requirements, as well as post-transaction - allowing the company to have further contact with the customer.

Comprehensive service relating to the refrigerated containers consists of providing the possibilities to perform many activities at the same time in one place or by one operator who is responsible for these steps completion. Using comprehensive service in the port, the client does not have to contact various contractors, as port ensures it. In addition, these services can be provided to the customer under one agreement of a comprehensive logistics service. This fact means that the contractor does not purchase separate services from the providers, but whole services necessary to ensure the proper logistics service of the load.

A comprehensive logistics service related to refrigerated containers in the seaport may consist of different activities, including transportation, overloading, storage, containers maintenance, veterinary control and customs, insurance, freight forwarding, distribution, advertising, consulting, etc. The most important services for these containers are connected with the specificity of transported cargo, mainly port has to ensure and monitor cargo storage conditions, as well as plug in the container to the electrical power source. Analysis of services offered by European container terminals showed that a comprehensive package of logistics services for refrigerated containers might include (Filina-Dawidowicz and Postan, 2015):

1) basic services (transportation, forwarding, terminal services, storage);

2) supplementary services:

- X-ray, washing, weighing of container, refrigeration unit service, transport means hiring,

- customs, veterinary and phytosanitary cargo control,
- preparing and coordinating of documentation flow,

- informing about service process, consulting,

- advertising, marketing, commercial and financial services,

- inventory management, demand forecasting etc.

Follows from the foregoing, the logistics services for the refrigerated containers can be either simple or complex, that are composed of different elements and may concern different activities, in it technical, organizational, marketing etc. Comprehensive service for refrigerated containers in ports is often supported by extensive IT systems (Filina-Dawidowicz and Troynina, 2015), which usage facilitates and accelerates the implementation of individual processes (Török et al., 2017).

\section{Criteria for comprehensive service}

Analyzing the criteria for the evaluation of comprehensive customer service in the port, attention should be drawn to customer needs. Service dimensions concerning port services have been proposed by Lu et al. (2011). They include port facilities and equipment, port costs, customer orientation, IT service, staff service ability, service efficiency, general service etc. Such kind of dimensions does not take into account the quality of port services.

The Authors of presented paper attempt to identify the criteria for the assessment of complexity of logistics services in seaports. For this purpose, the selected criteria have been proposed (Table 2). They form a set of the most common aspects of assessing the quality of logistics services, in the opinion of various authors, such as Kisperska-Moroń and Krzyżaniak (2009), Kempny (2008), Filipiak and Panasiuk (2008), Brdulak (2012). These criteria were not earlier applied to the study of refrigerated containers comprehensive service.

The analysis comprised 12 criteria of logistics services influencing on customer satisfaction. They allow examining the port services as the integral link in transport and logistics chains.

\section{Material and methods of research}

In order to accomplish the research aims the special questionnaire was developed and survey was carried out. The conducted research had quantitative character. Prepared questionnaire contained 8 questions, plus additional questions about the person completing the survey. Posted survey questions had mostly closed character, but some of them were semi-opened, with the possibility of issuing respondent's own opinion.

The surveys on customer satisfaction with the refrigerated containers service were conducted in December 2015 in Polish seaports located in Gdansk, Gdynia and Szczecin. Refrigerated containers handling in Polish seaports currently is performed in five container terminals (Filina-Dawidowicz and Troynina, 2015): Deepwater Container Terminal Gdansk (DCT Gdansk), Gdansk Container Terminal (GTK), Baltic Container Terminal in Gdynia (BCT), Gdynia Container Terminal (GCT) and DB Port Szczecin (DB PS). These terminals support both 


\begin{tabular}{|c|c|}
\hline Criterion & Description \\
\hline Timeliness of deliveries & Punctuality, delivery exactly within the prescribed time (Kisperska-Moroń and Krzyżaniak, 2009) \\
\hline Faultlessness of deliveries & $\begin{array}{l}\text { Compliance assortment of supplies to customer specification without unexpected replacements or mistakes } \\
\text { (Kisperska-Moroń and Krzyżaniak, 2009) }\end{array}$ \\
\hline Completeness of deliveries & Ability of suppliers to provide the full specification of the ordered products, delivery according to the order (Kempny, 2008) \\
\hline Reliability of deliveries & $\begin{array}{l}\text { Reliability means that the products will be delivered in accordance with the due date, without cargo damage, invoices will be } \\
\text { properly prepared, without mistakes, delivery will go to the appropriate place, as well as compliance assortment and number } \\
\text { of ordered products will comply with the order (Kempny, 2008) }\end{array}$ \\
\hline Price & $\begin{array}{l}\text { The cost of delivery is one of the main categories, which determines the processes occurring in the market. The price is a value } \\
\text { expressed in monetary units, which the buyer agrees to pay for goods or services (Filipiak and Panasiuk, 2008) }\end{array}$ \\
\hline Availability of services & $\begin{array}{l}\text { Deals with company localization, opening hours, services waiting times, the availability of information about the company and } \\
\text { offered services, easy and smoothly contact, etc. (Frąś, 2014) }\end{array}$ \\
\hline Frequency of deliveries & Specifies the traffic number at set time (during the day, week, month) (Kempny, 2008) \\
\hline Deep Assortment & $\begin{array}{l}\text { Refers to a merchandising strategy where the logistic provider offers to stock a number of variations of the same service line } \\
\text { (Zimon, 2015) }\end{array}$ \\
\hline Flexibility of deliveries & $\begin{array}{l}\text { Ability to adapt time (eg. the day and night), size, assortment and way of delivery to the needs and expectations of customers } \\
\text { (Kempny, 2008) }\end{array}$ \\
\hline Level of Customer Service & $\begin{array}{l}\text { It is the act of taking care of the customer's needs by providing and delivering professional, helpful, high quality service and } \\
\text { assistance before, during, and after the customer's requirements are met (Frąś, 2014) }\end{array}$ \\
\hline Innovativeness & $\begin{array}{l}\text { Logistics innovation is "streamlining, the new value from customer point of view, which is reflected in the market value and is } \\
\text { the basis for the development of logistics services and strategy building on the market" (Brdulak, 2012) }\end{array}$ \\
\hline Computerization & Process of introducing IT solutions that support enterprises or institutions operation (Adamczewski, 2005) \\
\hline
\end{tabular}

conventional containers servicing and those with dangerous and perishable cargo. The questionnaires were sent online to representatives of these 5 container terminals. One completed questionnaire from each terminal filled out by appropriate manager was considered in the research.

The dynamics of the overall container handling in Polish container terminals is presented in Fig. 1. A total number of containers handled in 2015 in analyzed ports is 1,862 mln TEUs (Data from BCT, 2016; Data from DB, 2016; Data from DCT, 2016; Data from GCT, 2016; Data from GTK, 2016), where the share of refrigerated containers is approximately $5-7 \%$.

In total, Polish seaports have 1656 plugs for these containers connections to an electrical power source, most of which have BCT Gdynia, which could plug in simultaneously 600 refrigerated containers (Table 3) (Filina-Dawidowicz and Troynina, 2015).

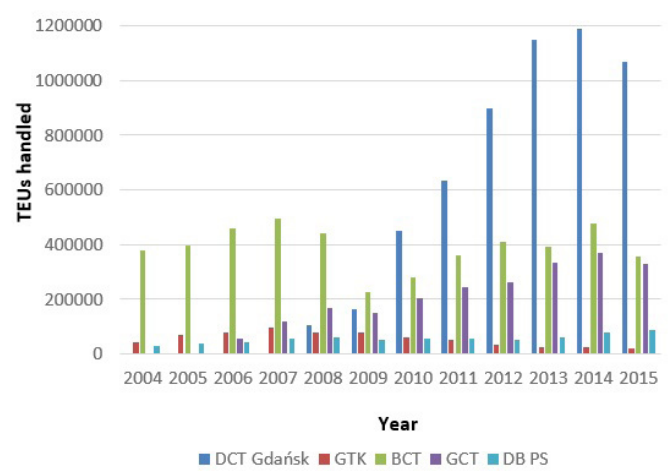

Fig. 1 Containers handling in Polish container terminals (Data from BCT, 2016; Data from DB, 2016; Data from DCT, 2016; Data from GCT, 2016; Data from GTK, 2016)
Table 3 Chosen parameters of polish container terminals (Data from BCT, 2016; Data from DB, 2016; Data from DCT, 2016; Data from GCT, 2016; Data from GTK, 2016)

\begin{tabular}{cccccc}
\hline & \multicolumn{5}{c}{ Port / terminal } \\
Parameter & $\begin{array}{c}\text { Gdańsk } \\
\text { DCT } \\
\text { Gdańsk }\end{array}$ & GTK & BCT & GCT & DB PS \\
& 650 & 367 & 800 & 450 & 650 \\
\hline $\begin{array}{c}\text { Quay length [m] } \\
\text { Overloading rate per } \\
\text { crane [cont/h] }\end{array}$ & 35 & 35 & 31 & 25 & 23 \\
$\begin{array}{c}\text { Storage capacity } \\
\text { [thd. TEU] }\end{array}$ & 29 & 4 & 20 & 6,5 & 5 \\
$\begin{array}{c}\text { Annual handling } \\
\text { capacity }\end{array}$ & 1250 & 100 & 750 & 400 & 120 \\
$\quad \begin{array}{c}\text { [thd. TEU] } \\
\text { Plugs number }\end{array}$ & 420 & 95 & 600 & 384 & 157 \\
\hline
\end{tabular}

Despite advanced infrastructure possession, these ports pay considerable attention to developing of logistics services in order to raise the level of customer satisfaction with the port service.

\section{Research results}

The results of the interviews concerning the importance of services complexity and level of satisfaction with complexity of services in a seaport, carried out with 5 Polish container terminals operators are presented in Fig. 2. The responses were provided on the five-point Likert scale (1 to 5), where 1 signifies the lowest value and 5 - the highest value. The questionnaires were filled by terminals managers, who have high qualifications and experience in transport and logistics field. 


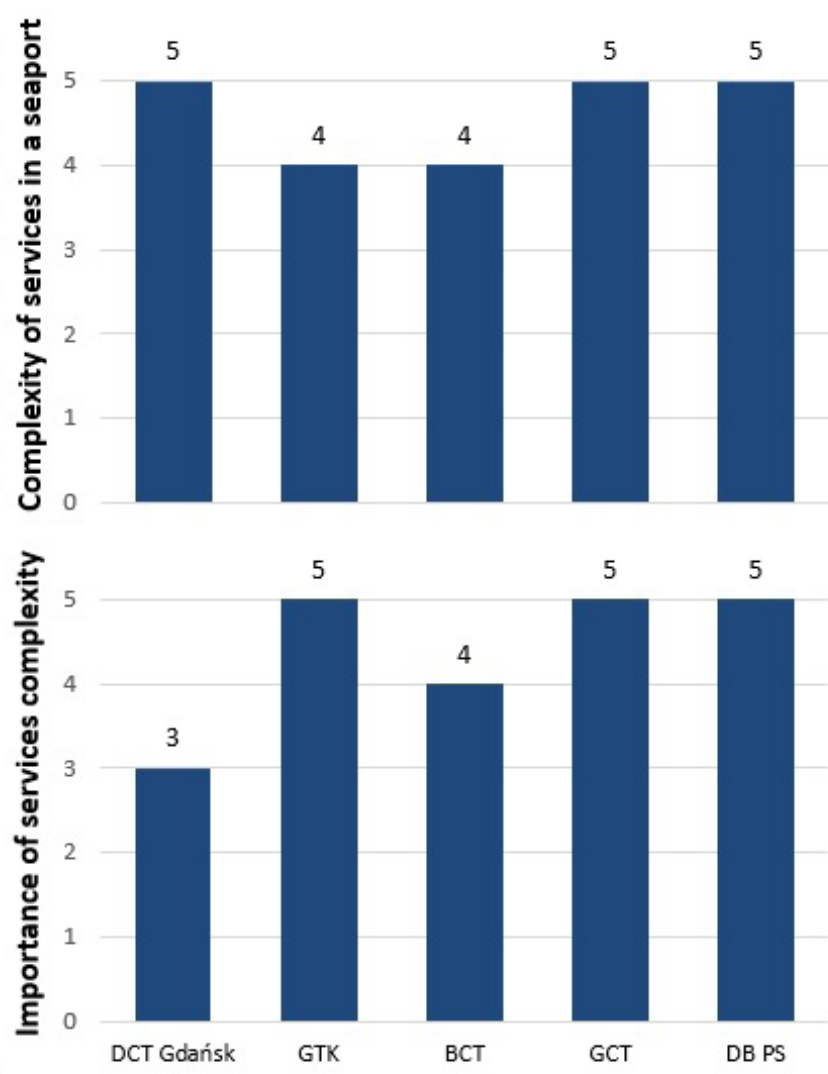

Fig. 2 Importance of services complexity and level of satisfaction with complexity of services

In the opinion of 5 container terminals representatives the comprehensive services are very important in seaports functioning. Similarly, respondents admitted high evaluations accessing the level of customer satisfaction in the field of comprehensive services in ports. Only the DCT Gdańsk representative evaluated the comprehensive services on average level of satisfaction. Therefore, it can be assumed that in DCT Gdańsk opinion the analysed criterion is less important for customers.

In Fig. 3 the evaluation of respondents connected with profits of services complexity was shown. As a result of conducted research, it was concluded that high-level customer satisfaction and shorter service time have the most profits from ports point of view. An average grade point in this case was $4.8 \mathrm{pt}$. In turn, the increase in demand attributed by seaports providers is the least important during comprehensive services offering (average grade point $-3.2 \mathrm{pt}$.).
The hierarchy of importance criteria in opinion of chosen container terminals was shown in Fig. 4. In order to carry out the analysis twelve attributes influencing the assessment of comprehensive services provided by refrigerated containers in seaports were taken.

Respondents assessed that for them the most important criteria are: good level of customer service (4.8 pt.) and timeliness of deliveries (4.4 pt.). In turn, wide range of assortments and flexibility of deliveries were classified as the least important criteria (3 pt.).

Furthermore, in opinion of the representatives of 5 seaports the good level of customer service and price are the most respected among 12 chosen criteria (Fig. 5). Evaluation in the case of these criteria was 4.8 pt., where 5 means very high level of a criterion compliance. The lowest points number providers attached to wide range of assortment ( 3 pt.). Therefore, it can be assumed that this criterion in the slightest degree influences the level of satisfaction with reference to the comprehensive services of refrigerated containers.

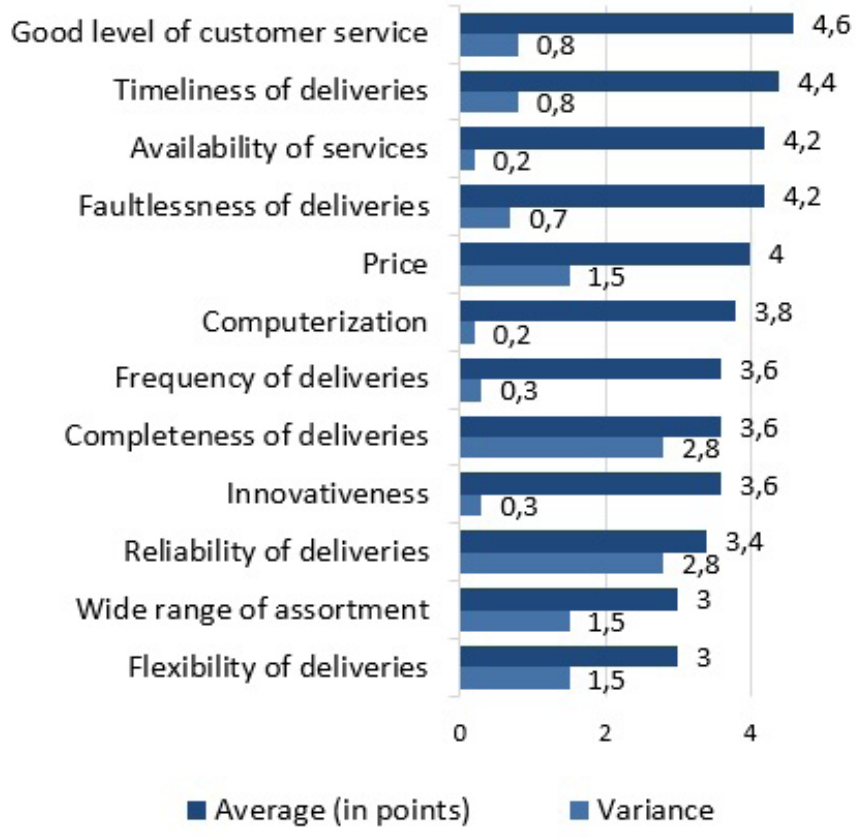

Fig. 4 Importance of the criteria connected with services complexity
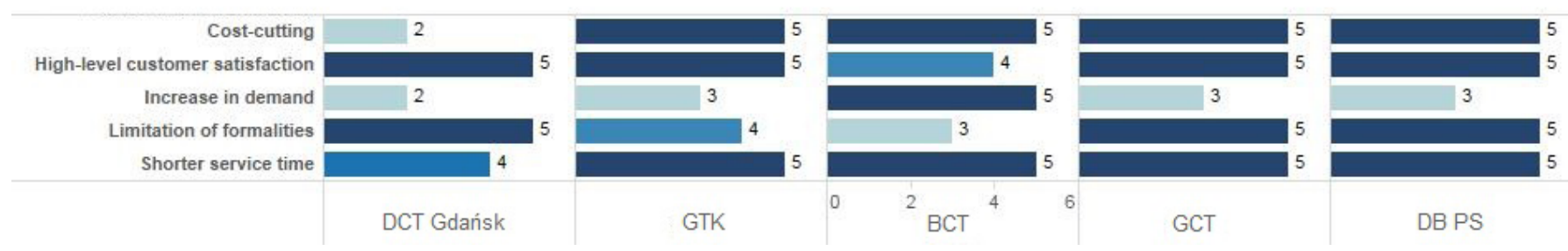

Fig. 3 Profits of services complexity 


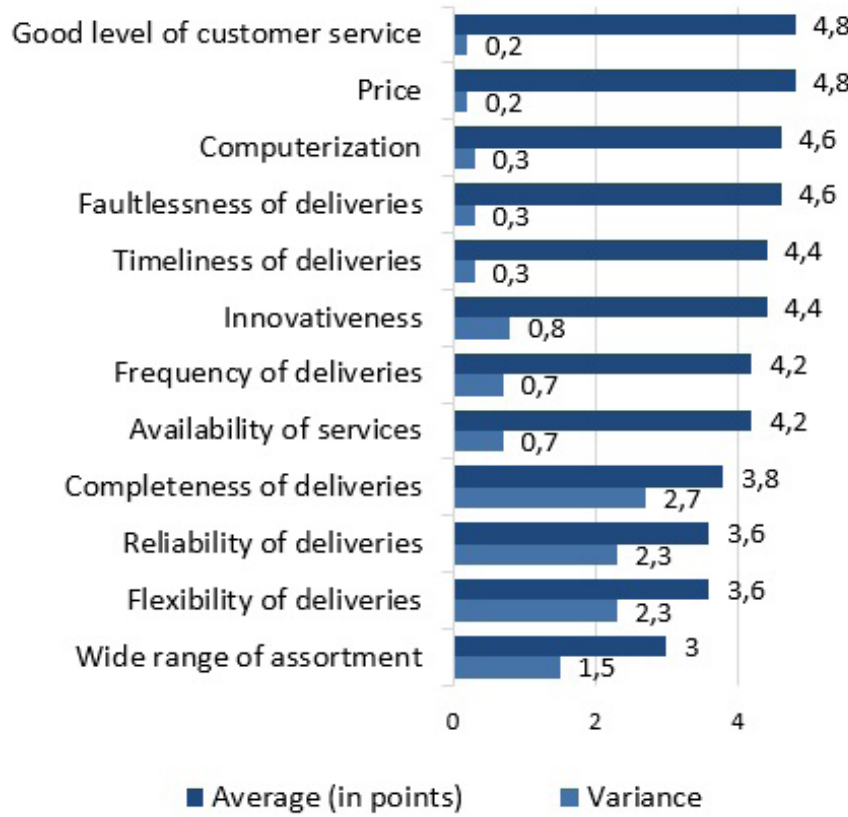

Fig. 5 Implementation of the criteria connected with complexity of services

To sum up the criteria applied for assessment of the comprehensive services in seaports, it can be concluded that good level of customer service in the opinion of ports is the most important criterion; in this respect it is implemented to the greatest extent. It can be supposed that also for customers this criterion has to be important and influential on choice of container terminal, which offers comprehensive services of refrigerated containers. The ranking and weights of importance and implementation of selected criteria was achieved.

\section{Discussion}

Examining the opinions of ports representatives on the satisfaction of their clients in terms of the complexity of logistics services allows looking at the stated problem from the side of service provider. It is important to explore and understand the position of the service providers about the needs and expectations of potential recipients. On this basis, the confrontation can be made with respect to future evaluations and reviews from customers of seaports services.

The role of the port as an integrator of logistics services may also be discussed. The concept of comprehensive logistic service has not yet fully implemented in European ports. The studies and observations indicate that not in all cases, the port acts as an integrator or logistics operator. In some ports there is still a number of services that is outsourced by the forwarder, for example, refrigerated container repair, washing, etc., while the port is only responsible for basic services execution.

The result of the study is also interesting, as among criteria connected with services complexity the lowest score was given to the wide range of assortment, reliability and flexibility of deliveries. It can be assumed that the examined ports do not notice the need to offer wide package of services or to expand it, since the impact on customer satisfaction will be small. Regarding this it would be important to examine the opinion of the customers of these terminals.

\section{Conclusion}

This paper is one of the first devoted to evaluating the customer satisfaction of comprehensive service process of refrigerated containers in seaports. Taking into account these goods specificity and logistic approach to their service analysis, the criteria for assessment of the level of customer satisfaction were proposed and analyses of survey among ports was carried out.

The research showed that the complexity of refrigerated containers handling in ports is important. Similarly, respondents admitted high marks for customer satisfaction in terms of complexity of services provided at their ports. In turn, it was examined that high-level customer satisfaction and shorter service time form the most profits for ports, while increase in demand - the smallest. In the opinion of services providers' representatives a good level of customer service, in terms of the services complexity, is on the first place among the most important criteria both from the point of view of importance and its implementation. At the same time, the least important was the wide range of assortment, both in terms of importance and the implementation directory in seaports.

Achieved results show the ranking of criteria importance and implementation, as well as their weights. On the basis of this data the assessment model of comprehensive service may be developed.

The future work will cover the examination of the nature and range of services forming the comprehensive service of refrigerated containers in ports, as well as complex comparative assessment of set criteria. In addition, it is planned to investigate the ports customers' satisfaction on the complexity of refrigerated containers handling at container terminals, including shipping lines and agencies, freight forwarders etc.

\section{References}

Adamczewski, P. (2005). Stownik informatyczny. (Dictionary of information technology.) Helion, Gliwice, Poland. (in Polish)

Brdulak, H. (2012). Logistyka przyszłości. (Logistics of future.) Polskie Wydawnictwo Naukowe, Warsaw, Poland. (in Polish)

Caceres, R. Ch., Paparoidamis, N. G. (2007). Service quality, relationship, trust, commitment and business-to- business loyalty. European Journal of Marketing. 41(7-8), pp. 836-867. https://doi.org/10.1108/03090560710752429

Corman, F., Xin, J., Negenborn, R. R., D'Ariano, A., Samà, M., Toli, A., Lodewijks, G., (2016). Optimal Scheduling and Routing of Free-range AGVs at Large Scale Automated Container Terminals. Periodica Polytechnica Transportation Engineering. 44(3), pp. 145-154.

https://doi.org/10.3311/PPtr.8620

Data from BCT terminal and seaport Gdynia. 01.2016.

Data from DB Szczecin terminal and seaport Szczecin. 01.2016.

Data from DCT terminal and seaport Gdańsk. 01.2016.

Data from GCT terminal and seaport Gdynia. 01.2016. 
Data from GTK terminal and seaport Gdańsk. 01.2016.

Dehdari1, M., Jafari, H. (2013). An Empirical Study on Customer Satisfaction in Pakistanian Container Ports Based on Kano Model. International Research Journal of Applied and Basic Sciences. 4(5), pp. 1245-1251.

Drewry Maritime Research. (2015). Reefer Shipping Market Annual Review and Forecast 2015/16. Drewry Publishing, London.

Esztergár-Kiss, D., Csiszár, Cs. (2016). Multicriteria Analysis of Hungarian Journey Planners. Periodica Polytechnica Transportation Engineering. 44(2), pp. 97-104. https://doi.org/10.3311/PPtr.8570

Filina-Dawidowicz, L., Postan, M. (2015). Directions of services development of European seaports specialized in perishable goods handling. Zeszyty naukowe Uniwersytetu Szczecińskiego, Ekonomiczne problemy ustug. 119, pp. 85-98.

https://doi.org/10.18276/epu.2015.119-06

Filina-Dawidowicz, L., Troynina, A. (2015). Wsparcie informatyczne procesów podejmowania decyzji podczas obsługi kontenerów chłodniczych w portach morskich. (IT support of decision-making processes during handling of refrigerated containers in seaports.) Logistyka. 4, pp. 31813191. (in Polish)

Filina-Dawidowicz, L., Wiktorowska-Jasik, A. (2013). Kompleksowa usługa logistyczna jako wyznacznik konkurencyjności portu morskiego. (Comprehensive logistics service as a determinant of seaport's competitiveness.) In: Systemy zarzadzania logistycznego w transporcie morskim. (Logistics management systems in maritime transport.) pp. 187-195. Wydawnictwo Zapol, Szczecin, Poland. (in Polish)

Filipiak, B., Panasiuk, A. (2008). Przedsiębiorstwo ustugowe. Zarządzanie. (Service company. Management.) Polskie Wydawnictwo Naukowe, Warsaw, Poland. (in Polish)

Frąś, J. (2014). Wybrane instrumenty pomiaru jakości usług logistycznych. (Selected instruments for measuring the quality of logistics services.) Zeszyty Naukowe Uniwersytetu Szczecińskiego, 803, Finanse, Rynki Finansowe, Ubezpieczenia. 66, pp. 297-317. (in Polish)

Gajewska, T., Grigoroudis, E. (2015). Importance of logistics services attributes influencing customer satisfaction. In: 4th IEEE International Conference on Advanced Logistics and Transport (ICALT), Valenciennes, France, May. 20-22, 2015. pp. 53-58. https://doi.org/10.1109/ICAdLT.2015.7136590

Galkin, A. (2015). System approach for logistics distribution, network's organization and planning. International Journal of Automation, Control and Intelligent Systems. 1(2), pp. 27-33.

Grant, D. B., Lambert, D. M., Stock, J. R., Ellram, L. M. (2006). Fundamentals of Logistics Management. McGraw-Hill Higher Education, Boston, USA. pp. 44.

Grigoroudis, E., Siskos, Y. (2010). Customer satisfaction evaluation: Methods for measuring and implementing service quality. Springer, New York, USA.

Grzelakowski, A. S., Matczak, M. (2006). Ekonomika i zarzadzanie przedsiębiorstwem portowym. Podstawowe zagadnienia. (Economics and management of port enterprise. Basic issues.) Wydawnictwo Akademii Morskiej w Gdyni, Gdynia, Poland. (in Polish)

Grzybowska, K. Kovács, G. (2017). The modelling and design process of coordination mechanisms in the supply chain. Journal of Applied Logic. 24, part A, pp. 25-38.

https://doi.org/10.1016/j.jal.2016.11.011

Jafari, H., Hunson, A., Jafari, H. (2013). Evaluation of Customer Satisfaction in Iraqi Container Ports. International Journal of Open Scientific Research. 3(1), pp. 1-9.
Kempny, D. (2008). Obstuga logistyczna. (Logistics service.)Wydawnictwo Akademii Ekonomicznej w Katowicach. Katowice, Poland. (in Polish)

Kisperska-Moroń, D., Krzyżaniak, S. (2009). Logistyka. (Logistics.) Instytut Logistyki i Magazynowania, Poznan, Poland. (in Polish)

Kotler, P., Armstrong, G., Saunders, J., Wong, V. (2000). Marketing. Podręcznik europejski. (Marketing. European manual.) Polskie Wydawnictwo Ekonomiczne, Warsaw, Poland. (in Polish)

Kovács, G., Bóna, K. (2009). Applying a multi-criteria decision methodology in the implementation of tenders for the acquisition of the infrastructure of logistics systems. Periodica Polytechnica Transportation Engineering. 37(1-2), pp. 39-44.

https://doi.org/10.3311/pp.tr.2009-1-2.07

Lisińska-Kuśnierz, M., Gajewska, T. (2014). Customer satisfaction with the quality of the logistic services. LogForum. 10(1), pp. 13-19.

Lorenc, A. K., Więcek, P. (2014). The routes optimization of picking up commodities in stock considering their natural characteristics. In: CLC 2013: Carpathian Logistics Congress Proceedings, Krakow, Poland, Dec. 9-11, 2013. TANGER Ltd., Ostrava, Czech Republic. pp. 307-312.

Lu, J., Gong, X., Wang, L. (2011). An Empirical Study of Container Terminal's Service Attributes. Journal of Service Science and Management. 4, pp. 97-109.

Meidute-Kavaliauskiene, I., Aranskis, A., Litvinenko, M. (2014). Consumer Satisfaction with the Quality of Logistics Services. Procedia-Social and Behavioral Sciences. 110, pp. 330-340. https://doi.org/10.1016/j.sbspro.2013.12.877

Misztal, K. (ed.), (2010). Organizacja i funkcjonowanie portów morskich. (The organization and operation of seaports.) Praca zbiorowa, Wydawnictwo Uniwersytetu Gdańskiego, Gdańsk, Poland. (in Polish)

Pluciński, M. (2013). Polskie porty morskie $w$ zmieniającym się otoczeniu zewnętrznym. (Polish seaports in the changing external environment.) Wydawnictwo CeDeWu, Warsaw, Poland. (in Polish)

Rodrigue, J.-P., Notteboom, T. (2014). Looking inside the box: evidence from the containerization of commodities and the cold chain. Maritime Policy \& Management: The flagship journal of international shipping and port research. pp. 207-227. https://doi.org/10.1080/03088839.2014.932925

Török, Á., Fedorko, G., Molnar, V., Husaková, N., Csiszár, Cs. (2017). How to Choose and When to Start Best ITS Projects That Enhance Logistic Performance? Periodica Polytechnica Transportation Engineering. 45(1), pp. 8-11. https://doi.org/10.3311/PPtr.9222

Yi, Y. (1989). A critical review on consumer satisfaction. In: Review of marketing. (Zeithaml, V. A. (ed.)), American Marketing Association, Chicago, USA. pp. 68-123.

Zhang, X. L., Zhang, K. Y., Zhang, X. F. (2010). Analysis of Port Authority to Improve Customer Satisfaction Based on DMAIC Mode of Six Sigma Management. Advanced Materials Research. 171-172, pp. 604-608. https://doi.org/10.4028/www.scientific.net/AMR.171-172.604

Zimon, D. (2015). Impact of the implementation of quality management system on operating cost for small and medium-sized business organizations affiliated to a purchasing group. International Journal for Quality Research. 9(4), pp. 551-564. 